\title{
The Implementation of Group Investigation E-Task in Activities Learning (GIETAL) in Higher Education
}

\author{
Sri Restu Ningsih, Ade Irma Suryani and Ilham Tri Maulana \\ STMIK Indonesia Padang, Indonesia \\ srirestuningsih@stmikindonesia.ac.id \\ adeirma@stmikindonesia.ac.id \\ ilhamtm@stmikindonesia.ac.id
}

\begin{abstract}
This study aimed to implement a learning model developed by the Group Investigation E-Task in Activities Learning (GIETAL) model for theoretical learning during the Covid-19 pandemic. The learning process that previously used conventional methods has been changed to online learning. For this reason, a practical and effective learning model is needed for students in higher education. The method used was the GIETAL model founded on the ADDIE method. The data processed after implementing this model were from the respondents consisting of 54 students of two lecturers. The results of testing the practicality of this study had a practical level of $86.66 \%$. It could be concluded that the GIETAL Model is beneficial in teaching Database Design courses during the Covid-19 pandemic. Furthermore, this implemented learning model was proven to improve student learning outcomes effectively; this was underlined by 51 students (94.44\%) graduating and passing the minimum criteria set in the semester learning plan. This research's final result was implementing a practical and effective GIETAL learning model for university students.
\end{abstract}

Keywords: Group Investigation, E-Task, ADDIE, practical, effective, GIETAL

\section{Introduction}

The Covid-19 pandemic that hit Indonesia had a terrible impact on various sectors. One of them is the education sector, which has experienced many changes during this pandemic. Students and educators cannot carry out the learning process face to face, but it is carried out online. As the pandemic continues and education is impossible in person, this uncertainty forces universities and schools to change the mode of the education system from campus to home (Tawafak et al., 2021). Furthermore, e-learning is gaining more impact in higher education, especially in mixed learning formats, so this new type of teaching and learning can be practiced in many ways (Nortvig, Petersen, and Balle, 2018).

The rapid development of internet technology and computer technology has modernized network information (Liu and Zhao, 2017). Online learning has become a vital learning model, along with developing information technology and intelligent devices popularized continuously (Wang, 2019). E-learning brings together two main areas, namely education and technology. First, the website must be supported by a computer network by implementing a client-server on the internet network (Aparicio, Bacao, and Oliveira, 2016). Second, web-based education systems can represent a very effective method of delivering learning experiences to students because they are widely distributed and easily accessible, regardless of location or time.

Many new types of learning mostly claim to consider a deeper understanding of the discipline combined with the essence of our humanity, emotional intelligence, critical thinking, and creativity. This kind of learning is called deep and meaningful learning (Mystakidis, Berki, and Valtanen, 2019). The learning model is a pattern that is always used to guide classroom learning and tutorials for lecturers in universities. Lecturer learning models can help students get information, ideas, skills, and ways of thinking and expressing thoughts and guide learning designers. Learning models can also be said as procedures or steps that educators need to take to facilitate active, participatory, and interactive learning to achieve educational goals, namely developing students' potential optimally (Ningsih, Effendi, and Syah, 2019). The rapid development of computer technology and penetration in various fields has made developments in the management of education in universities (Chen, 2018). However, conventional learning methods are still inadequate to date, and students must be responsible for their learning process, while teachers only function as mentors for students (Hursen, 2019). The effectiveness of online learning depends on proper planning and teaching to improve learning and overall student outcomes. Online learning can meet both active and passive learning needs (Lomovtseva and Korobeynikova, 2020). 
The results showed that the group investigation model was applied in the following steps: forming groups, identifying topics, planning investigations, carrying out investigations, preparing final reports, presenting final reports, and evaluating (Pratimi, Suhartono, and Salimi, 2019). According to previous research, the E-Task application is a system that provides task services from lecturers to students. Therefore, based on the opinion above, it can be concluded that the E-Task application is a system that implements the learning process and assignments online or indirectly with teaching lecturers (Ningsih, Suryani, and Aulia, 2019).

The learning process in the Database Design course is still using the conventional method, namely in lecturer to students. This traditional learning does not train students to interact and skillfully use computer technology. As a result, students do not gain valuable skills in technology and computers to prepare them for the future. This study aims to implement a learning application development, namely the Group Investigation E-Task in Activities Learning (GIETAL) model, a web-based cooperative learning model in making investigative group assignments given by lecturers to students. Tasks that are usually paper-based will change the paradigm into web-based projects given to lecturers through online media. This model can improve the quality of learning in students and can be used as an alternative to developing a more effective and efficient education system. From the implementation of the GIETAL model, it will be determined whether this model is practical and effective in online learning during the Covid-19 pandemic. This application is implemented using the PHP programming language and MySQL database. This learning media application is expected to help the distance learning process without always having to do it face-to-face.

In group cooperative learning, students will gain new, meaningful knowledge with better quality, contextual and relevance when compared to individual or independent learning (Harsono, 2008). However, in this study, the E-Learning Application was designed for non-formal educational institutions to process student registration, student attendance data, group discussions, give lessons, give and receive assignments, and online assessments (Fachrizal and Ramadhan, 2018). To this end, it is suggested that the educational environment should be enriched through educational methods that enhance students' ability to relate what they have learned to real-life, problem-solving skills and critical thinking (Maulana et al., 2019). Online learning systems are essential for improving thinking and innovation skills for higher education students. Statistical tests are more related to educational technology than the literature review (Chootongchai and Songkram, 2018).

\section{Literature Review}

Researches relevant to the development of cooperative learning models carried out are the research proposed by Yenni Anas, Hardeli, Azwir Anhar, Ramadhan Sumarmin (2018), International Journal of Higher Science and Technology, Application of Cooperative Learning Model Type Group Investigation (GI) in Improving School Student Biology Learning Competencies. This research is about applying the Group Investigation type of cooperative learning model to improve the learning competence of Biology Education Study Program Students, PPS FMIPA, Universitas Negeri Padang. The learning model can encourage students to interact actively in the Group Investigation (GI) type of cooperative learning. This study aimed to determine the process of increasing students' biology learning competence by applying Gl-type collaborative learning. This research was a classroom action research conducted in 3 cycles. Based on the study results, it can be concluded that there is an increase in students' biology learning competence through the application of the Group Investigation (GI) cooperative learning model (Santyasa, Kanca, and Sukra, 2019).

Research from Yhona Arinda, Insih Wilujeng, Heru Kuswanto (2019) with the Application Group Investigation (GI) Learning Model Assisted by Phet to Facilitate Student Scientific Work Skills. This study aims to measure students' scientific work skills by using the group investigation model with Phet. This research is quasiexperimental. Therefore, this study could not control the external variables that affect the results of this quasiexperimental research. However, the results showed that the scientific work skills of students who used the Cooperative Learning Group Type of Group Investigation with Phet model in the modelling class or implementing class had the same results with good categories, namely $80.01 \%$ and $77.3 \%$. It shows that using the Group Investigation (GI) model with Phet makes students' scientific work skills in the Good category (Arinda, Wilujeng, and Kuswanto, 2019).

Sopiah Sangadji's research (2016) entitled Application of Cooperative Learning with the Group Investigation Model to Improve Learning Achievement of Vocational High School Students in Indonesia. This study aimed to 
describe the application of the group investigation learning model in improving the learning achievement of vocational students in Indonesia. This study uses a qualitative approach and applied classroom action. This research is for the 1st-grade students of the SMK Sales Skills Program in Malang, Indonesia. Data collection techniques used are in-depth interviews, observation, documentation, literature study and tests. Data analysis techniques used interactive techniques. The results showed that: the group investigation learning model had been implemented well, and SMK students had better learning achievements. Therefore, the investigative group learning model can improve the learning achievement of vocational students (Sangadji, 2016).

\section{Methods}

One of the models for designing learning is the ADDIE model. The ADDIE model, which stands for Analysis, Design, Development, Implementation, Evaluation, guides effective, dynamic learning and supports learning itself. The ADDIE model is a system-oriented general learning design model. For more details, see the schematic in Figure 1.

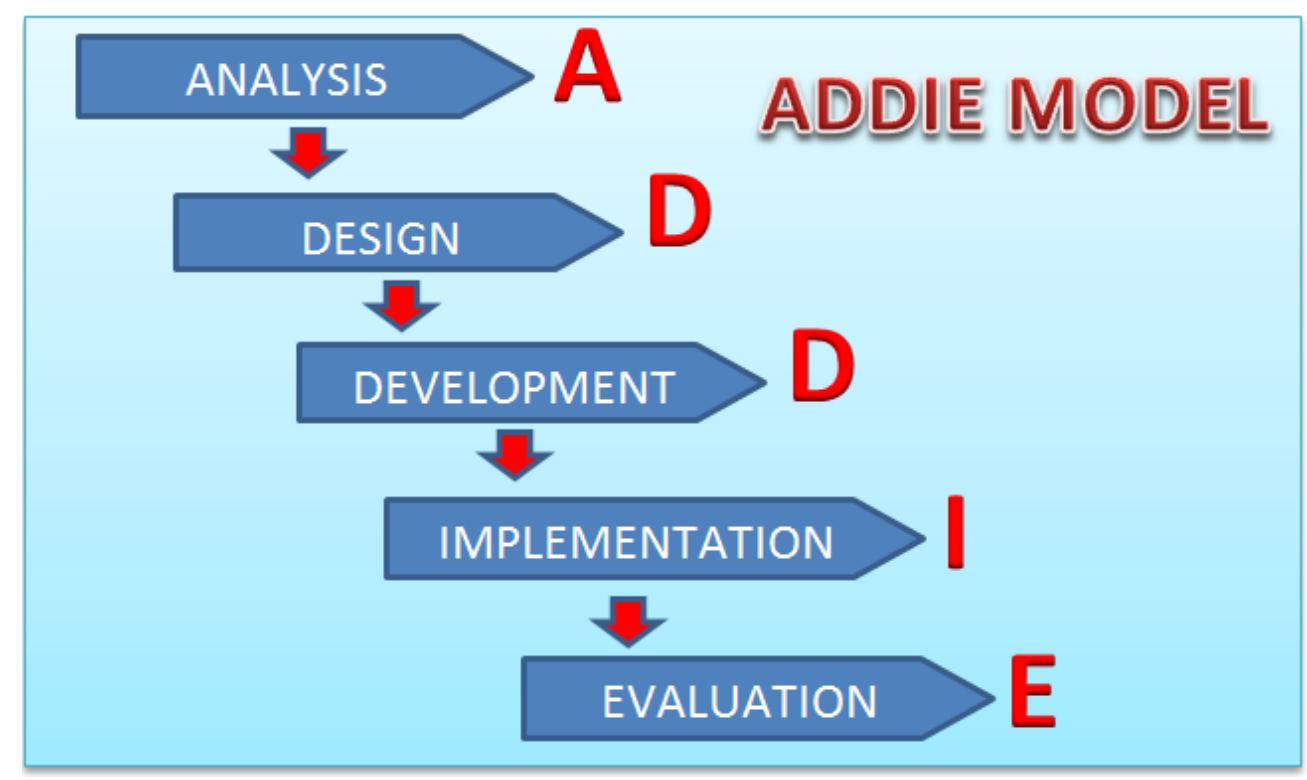

Figure 1: ADDIE model

The development of the ADDIE model consists of 5 development steps, namely:

1. Analysis. At this stage, identification of problems contained in learning, curriculum and learning objectives, analysis of the needs of students and teachers in the learning process is carried out.

2. Design. This stage is to verify problem-solving and design the learning models needed to solve problems in the learning process.

3. Development. This stage is to build and validate the application of the learning model that has been designed. This process is time-consuming and complicated.

4. Implementation. At this stage, the implementation of the learning model that has been built and developed is carried out.

5. Evaluation. This stage assesses the quality of the development product before or after implementing the developed learning model, whether there are still weaknesses or shortcomings that need to be improved.

\subsection{Data Analysis}

Group Investigation is a cooperative learning model that includes student participation and activities to find their learning materials (information) through available materials, such as textbooks, or students can search through the internet. The Group Investigation Model learning model stages consist of 6 steps, as shown in Figure 2. 


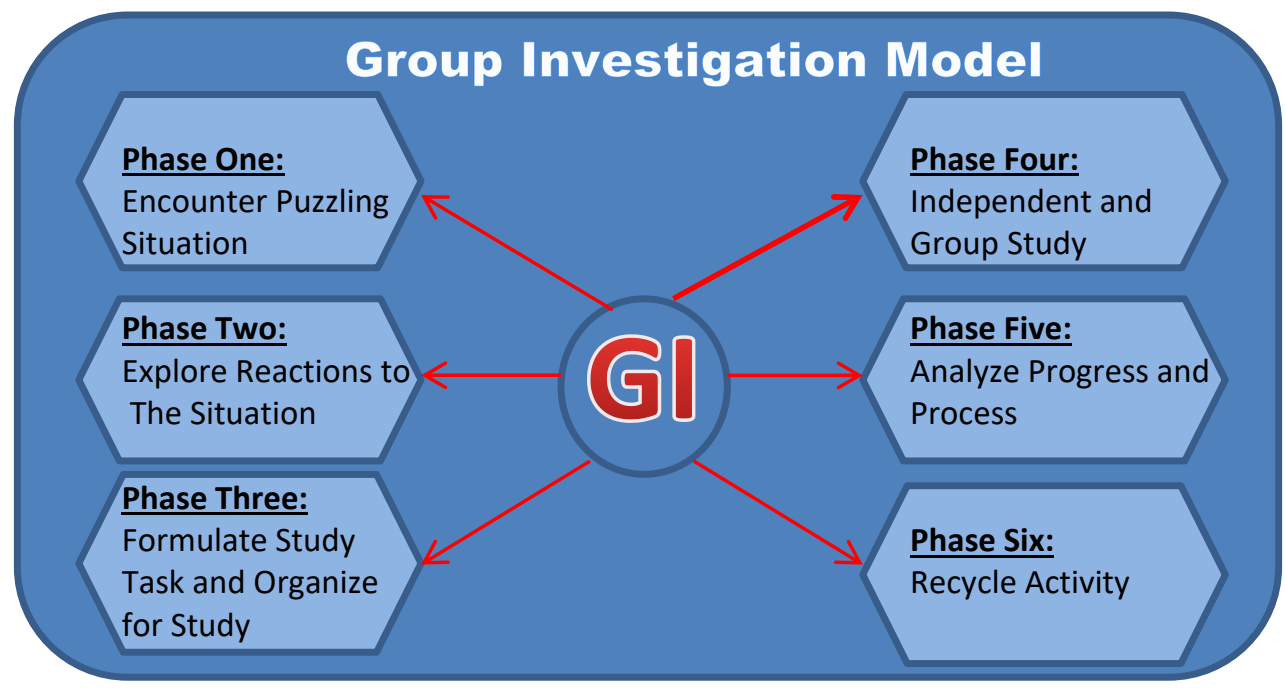

Figure 2: Group investigation model stages

Figure 2 shows the steps of the group investigation type learning model (Group Investigation), which can generally be described as follows: groups

1. Organizing students into groups. Students are divided into groups of 4-5 students.

2. Planning learning assignments together with students in their respective groups.

3. Conduct an investigation. Lecturers direct students to seek information, analyze data and make conclusions.

4. Prepare a final report. Students prepare a report plan as presentation material.

5. Presenting the final report with a video presentation.

6. Evaluation. Students share information and ideas; then, the lecturer reinforces by evaluating each group's work and concluding the lesson.

The assumptions used as a reference for this group investigation type of cooperative learning model are:

1. Increasing students' creative abilities by developing the creative process towards awareness.

2. Focusing on emotional component more than intellectual component.

3. Increasing the chances of learning success in solving a problem is expected to start from understanding the emotional and irrational components.

Table 1 shows several comparison variables of the learning process used by lecturers conventionally and using the GIETAL model.

Table 1: Comparison of the learning process phenomenon in the database design course

\begin{tabular}{|c|l|l|l|}
\hline No. & \multicolumn{1}{|c|}{ Variable } & \multicolumn{1}{c|}{ Conventional } & \multicolumn{1}{c|}{ GIETAL } \\
\hline 1. & Learning Methods & Teacher Center Learning & Student Center Learning \\
\hline 2. & $\begin{array}{l}\text { Teaching and Learning } \\
\text { Process }\end{array}$ & Lecture and Take Notes & Interactive, cooperative, discussion \\
\hline 3. & Level of Creativity & Low Creativity & High Creativity \\
\hline 4. & Student Attitude & $\begin{array}{l}\text { Not enthusiastic, lazy, not } \\
\text { confident and not creative }\end{array}$ & $\begin{array}{l}\text { Enthusiastic, passionate, confident and } \\
\text { creative }\end{array}$ \\
\hline 5. & $\begin{array}{l}\text { Application of course } \\
\text { assignments }\end{array}$ & $\begin{array}{l}\text { Independent assignments and } \\
\text { group assignments }\end{array}$ & $\begin{array}{l}\text { Specifically to the Database Design group } \\
\text { assignment }\end{array}$ \\
\hline 6. & The final result & Low learning outcomes & High learning outcomes \\
\hline
\end{tabular}

\subsection{ADDIE Development Procedure}

The procedure for developing the Group Investigation E-Task in Activities Learning (GIETAL) learning model is illustrated in Figure 3. 


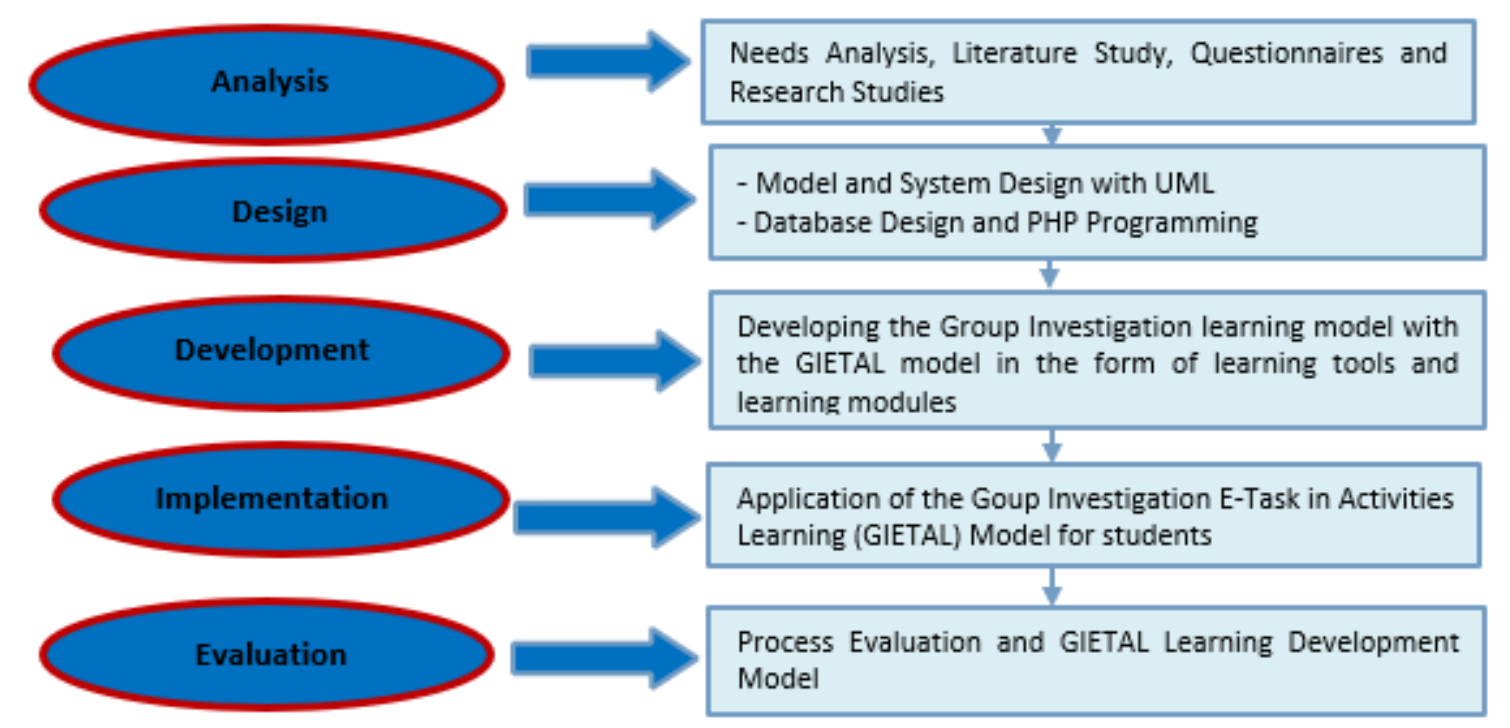

Figure 3: Stages of the procedure for the development of the e-task group investigation model in learning activities (GIETAL)

The development procedure of the GIETAL model used the ADDIE method, which consists of 5 stages, namely:

1. Analysis Stage. At this stage, identification and analysis of needs were carried out in developing the system and studying literature.

2. Design Stage. At this stage, the form of developed learning model would be verified or the appropriate system development method was selected. The steps taken at this stage (a) Observation (b) Material analysis, to analyze whether the material follows the expected competencies and knowing the appropriate material to be developed in the GIETAL model.

3. Development Stage. The following steps were taken at this stage: (a) Designing a prototype, namely making an initial design (prototype) of GIETAL learning media whose content was adjusted to the applicable syllabus and lesson plans. (b) Validation Phase. The validation used was material and media validation. Material validation was to see if the GIETAL learning media that has been designed follows the course syllabus. GIETAL learning media that have been developed were consulted and discussed with experts (lecturers). Validation activities were carried out to fill out validation sheets, and discussions until a valid and appropriate GIETAL learning media was obtained.

Table 2: Aspects of GIETAL validation

\begin{tabular}{|c|c|c|c|}
\hline No. & Aspects of & Data Collection Method & Instrument \\
\hline 1 & Content and interest & \multirow{2}{*}{$\begin{array}{l}\text { Discussion with learning media experts and } \\
\text { primary network education and training } \\
\text { teachers }\end{array}$} & \multirow{2}{*}{ Validation Sheet } \\
\hline 2 & Media and Language & & \\
\hline
\end{tabular}

Table 3: GIETAL validation questionnaire grid

\begin{tabular}{|c|c|c|c|}
\hline No. & Aspect & Assessment Indicator & No Item Question \\
\hline \multirow[t]{2}{*}{1} & \multirow{2}{*}{ Content and interest } & a) Content aspect & $1-9$ \\
\hline & & b) Supporting aspect & $1-2$ \\
\hline \multirow{2}{*}{2} & \multirow{2}{*}{ Media and Language } & a) Media & $1-11$ \\
\hline & & b) AspectLanguage aspect & $1-2$ \\
\hline
\end{tabular}

1. Evaluation stage. At this stage, activities were focused on evaluating whether the prototype (initial design version) could be used as expected and effectively to improve the quality and student learning outcomes. The following steps were carried out:

(a) Practicality Stage, a trial was carried out on one Database Design class and lecturers. The trial was carried out to see the practicality of the GIETAL learning media designed by students and lecturers filling out the questionnaires provided. 
Table 4: Practicality questionnaire grid by teachers

\begin{tabular}{|l|l|c|}
\hline No. & Assessment Indicators & No Question Items \\
\hline 1 & Ease of use & $1-4$ \\
\hline 2 & Time effectiveness & $5-8$ \\
\hline 3 & Media interpretation & $9-11$ \\
\hline 4 & Equivalence & $1-2$ \\
\hline
\end{tabular}

Table 5: Practicality questionnaire by students

\begin{tabular}{|l|l|c|}
\hline No. & Assessment Indicator & No Question Item \\
\hline 1 & Ease of use of media & $1-6$ \\
\hline 2 & Time required & $7-9$ \\
\hline 3 & Media appearance and attractiveness & $10-12$ \\
\hline
\end{tabular}

(b) Effectiveness Phase, the effectiveness aspect observed in the learning process using GIETAL learning media was student learning outcomes. Student learning outcomes were obtained by carrying out tests on students after students use GIETAL.

\section{Results}

\subsection{Concept of the GIETAL}

The Group Investigation E-Task learning model is a type of cooperative learning designed to get a unique role in completing all tasks and are responsible for that particular role in the group. What distinguishes group investigation from other types of cooperative learning is that group investigation involves students' ability to learn through inquiry.

The GIETAL learning model is an information technology product that lecturers and students can use to facilitate interaction in making student assignments presented on the website. On the other hand, teaching has also evolved to involve more flexibility in tasks, and learning stages, so modern technology now can give more alternatives (Zidoun, Dehbi, and Talea nd). All content, updates and activities are posted to this system, and students can manage their interactions via messages, email and online forums. From the statement above, we can see the concept of the GIETAL learning model in Figure 4.

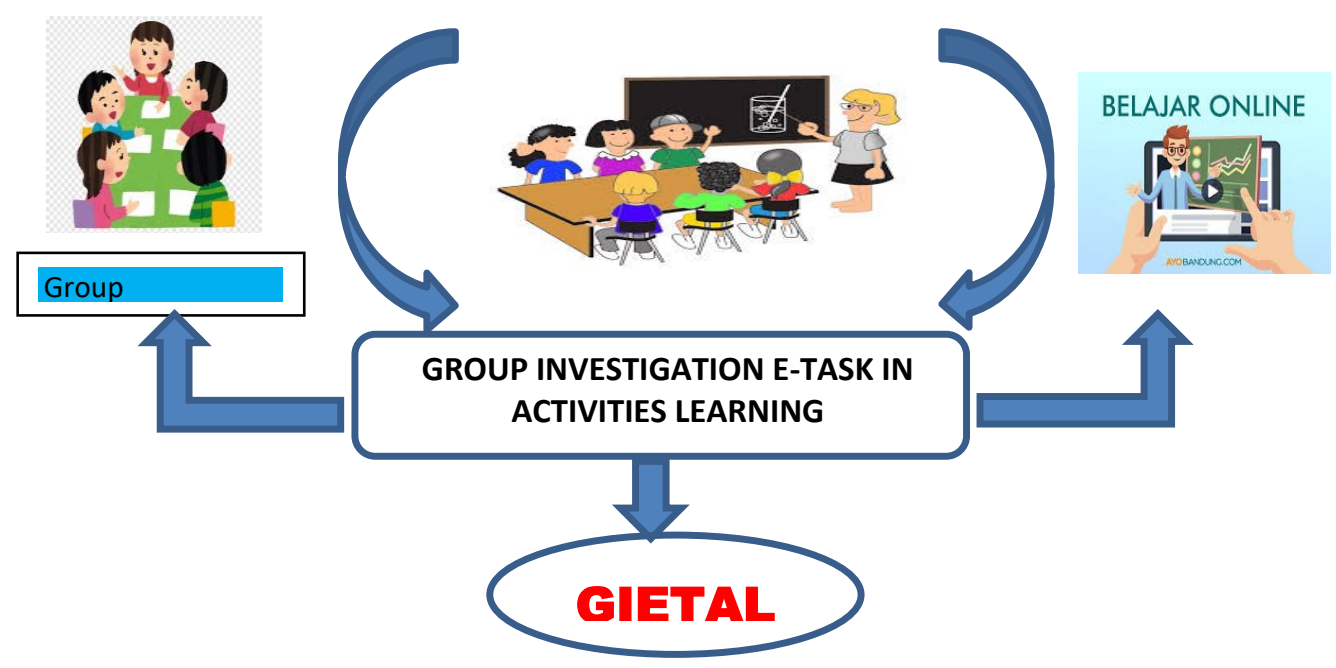

Figure 4: The concept of the GIETAL learning model

Figure 4, shows that in this learning process, the lecturer uses the group investigation model in giving assignments to students. For example, the lecturer will divide the students into several groups/teams consisting of 4-5 students to make group assignments in a class. In developing this learning model, the lecturer uses the website for the group investigation model to change the paradigm from a conventional-based learning model to a web-based learning model. Students discuss their group assignments via the web using the GIETAL model. This group discussion can be done by students anywhere and anytime, with unlimited time. 


\subsection{Use Case Diagram}

Use case diagram is modelling for the behaviour of the system to be made. Use case diagrams during the analysis process for requirements or requests to the design and understand how the system should work. For example, the admin use case diagram shows the sequence of interactions between the admin and the system, clearly seen in Figure 5.

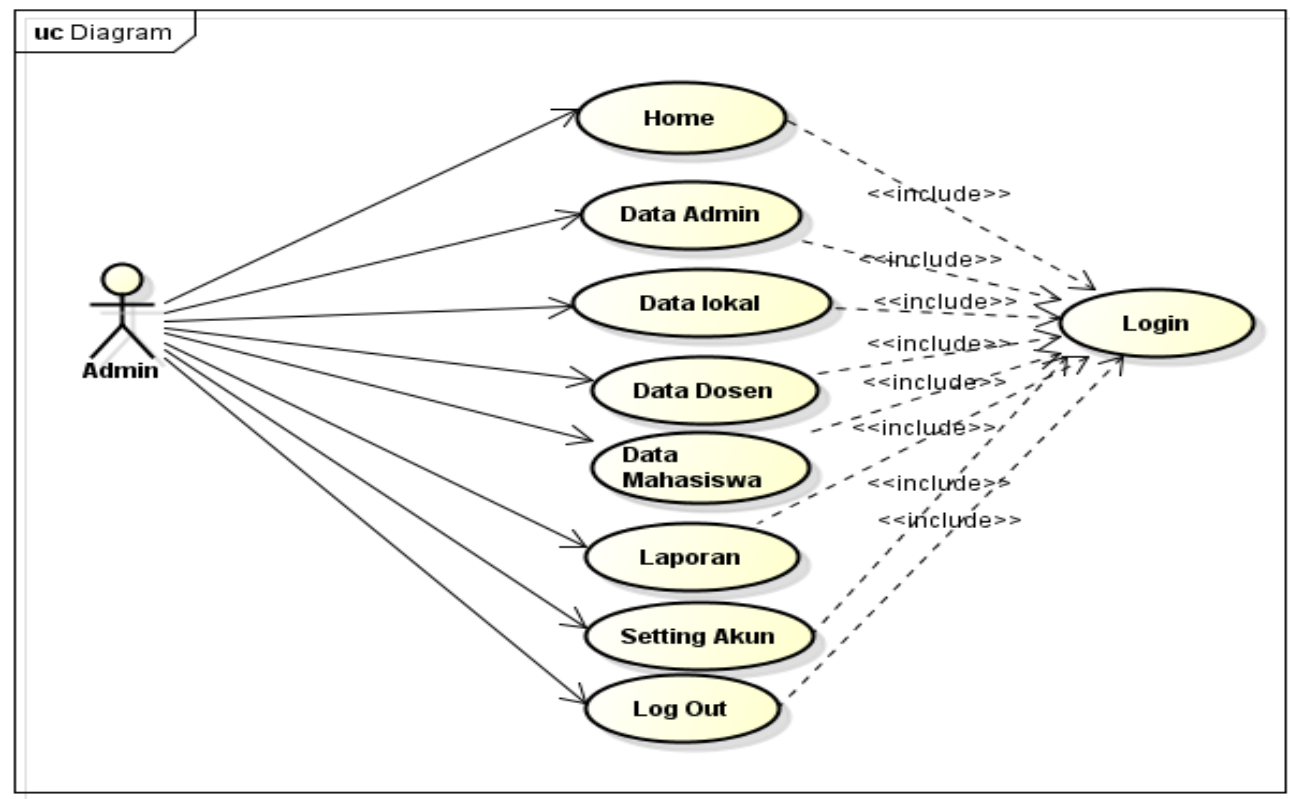

Figure 5: Admin use case diagram

In this learning model application, there are two users, namely lecturers and students. To find out what interactions are carried out between users and this information system and what functions users can perform as lecturers can be seen in Figure 6.

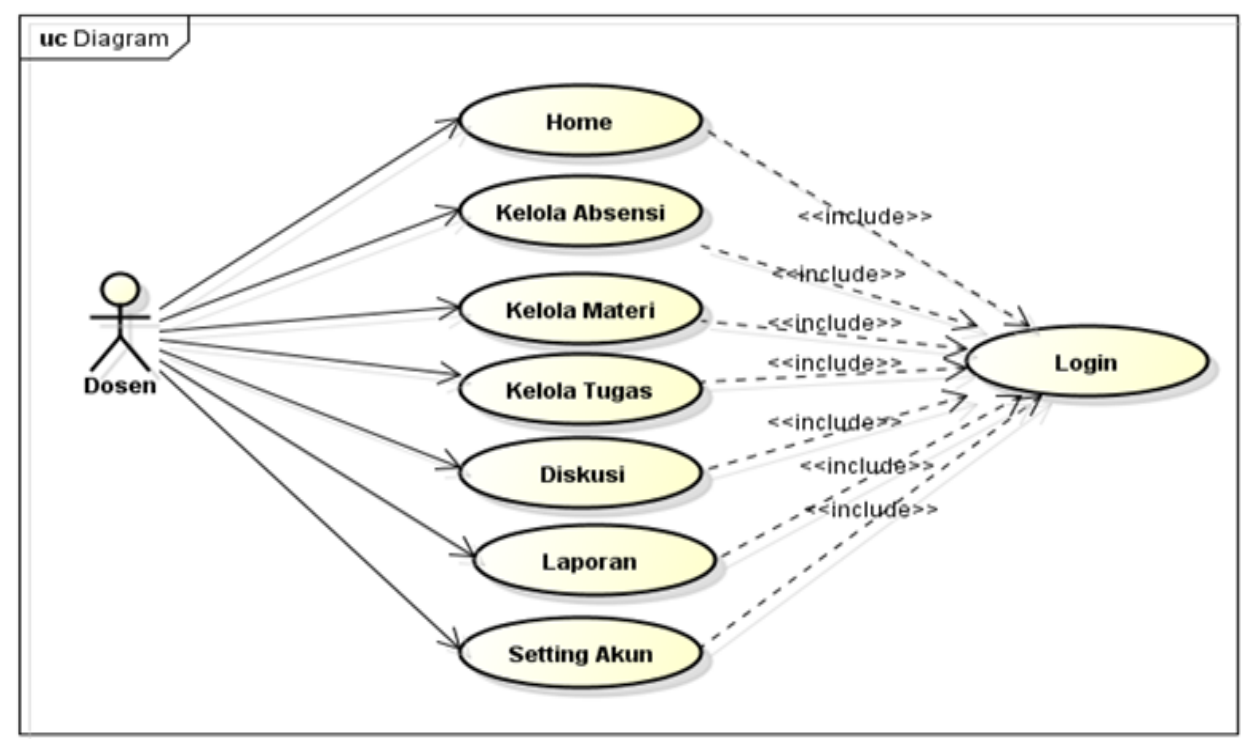

Figure 6: Lecturer use case diagrams

After logging in to enter the lecturer's main menu, the lecturer uses a case diagram to manage student attendance, manage materials, manage assignments, and discuss with students. After that, the lecturer reports the grades of student assignments in each class being taught. Lecturers can also change their accounts in the account settings menu. 
In Figure 7, the student use case diagram shows the sequence of interactions between students and the system.

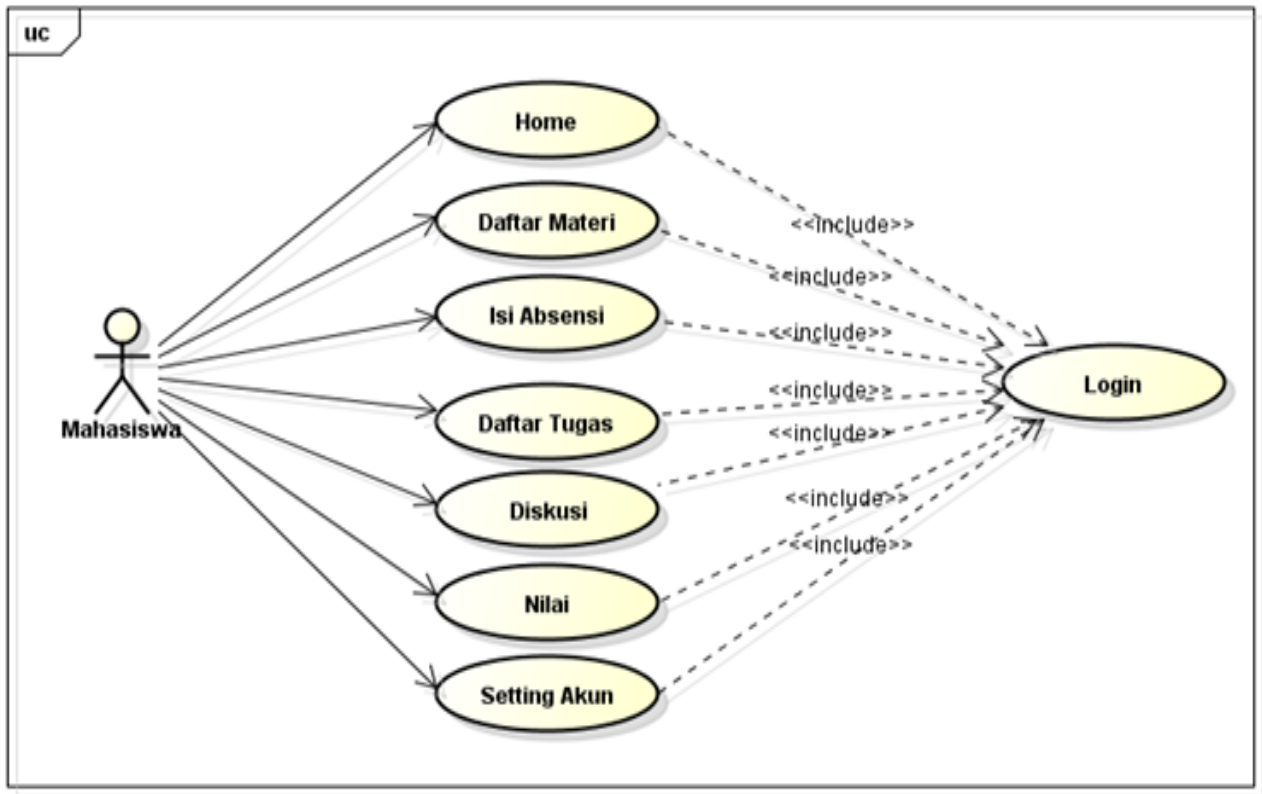

Figure 7: Student use case diagrams

In student use case diagrams, after logging in, students can see the list of materials given by the lecturer, fill in attendance, view task lists, conduct group discussions and see the grades given by the lecturer for their assignments. Students can also change their accounts in the account settings menu.

\subsection{Class Diagram}

Class Diagram is the relationship between classes and a detailed description of each class in the model, and also shows the attributes and class operations and constraints associated with the connected objects. In addition, the class diagram provides any information contained by each object. This information consists of the behaviour and elements included in the system objects. The class diagram in this system is presented in Figure 8.

In this system, there are several classes and functions that users of this system can perform. Some of these classes are student class, assignment class, material class, displaying grades that have been collected, submitting assignments, viewing grades and conducting assessments. Class registration to register to the system, add classes, edit classes, delete classes and search for classes. Classwork, class comments, view files, grade and submit assignments. 


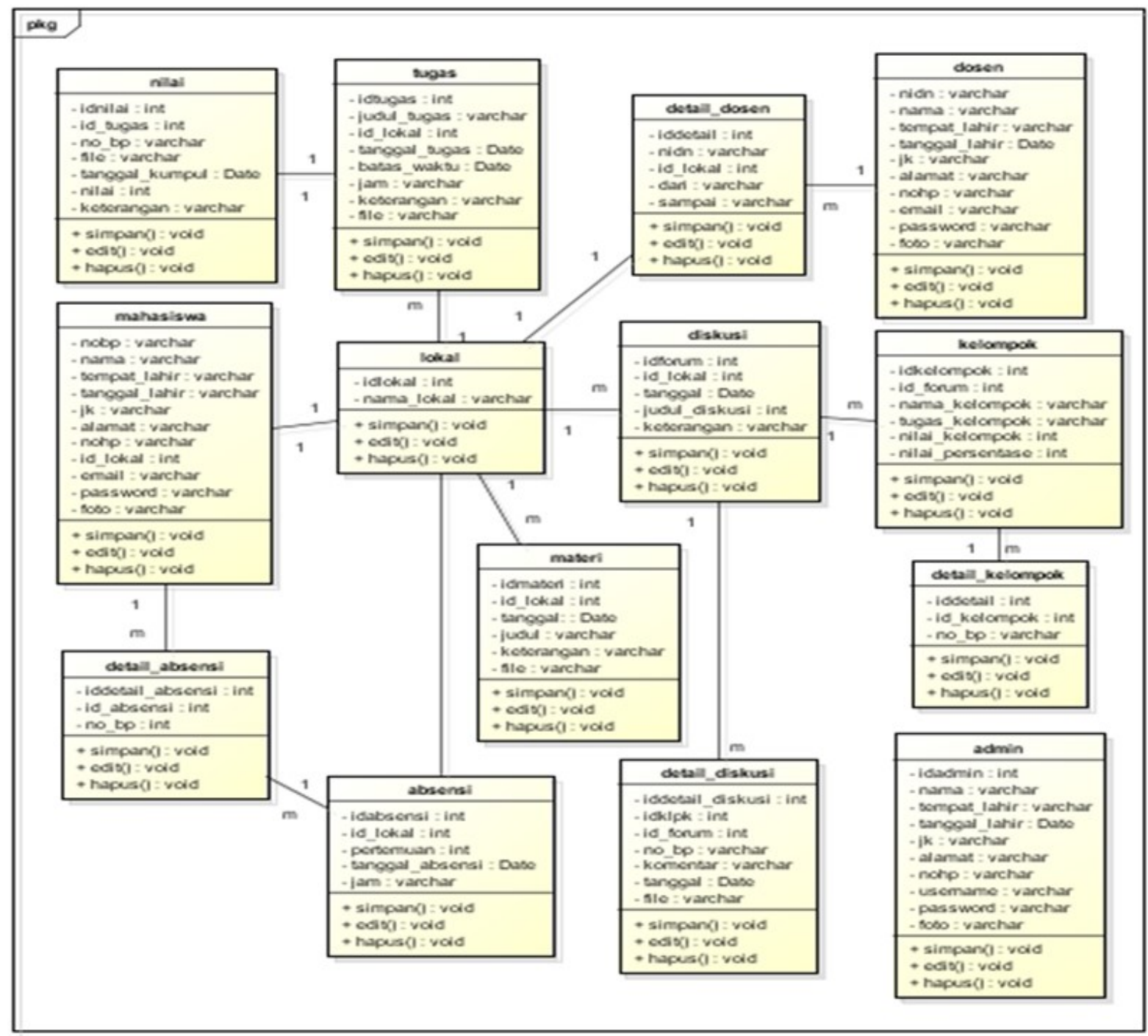

Figure 8: Class diagram

\subsection{System Implementation}

The system implementation stage is the procedure performed to complete the existing system design in the approved system design document and test, install and start using the new system. The purpose of the implementation phase is to complete the approved system design, test and document the required system programs and procedures, and ensure that the users involved can operate the new system and convert the old system to the new system. The results of the application of the GIETAL model can be seen in Figures 9 to 12 .

At this stage, the author describes the results of testing the system that has been implemented. The main page of the GIETAL learning model application in the Database Design course in Higher Education is home, about us, and login menus, which can be seen in Figure 9. On the main page, there are also three main choices, namely courses, students and lecturers. Students and lecturers must select the login menu to enter the login page view.

Figure 10 is a login page display. That is after students or lecturers select the login menu to enter the login page display. After entering the login page, students and lecturers must fill in data including username, password and level, namely the choice between lecturers or students. Then, students or lecturers can choose to log in to enter the system. 


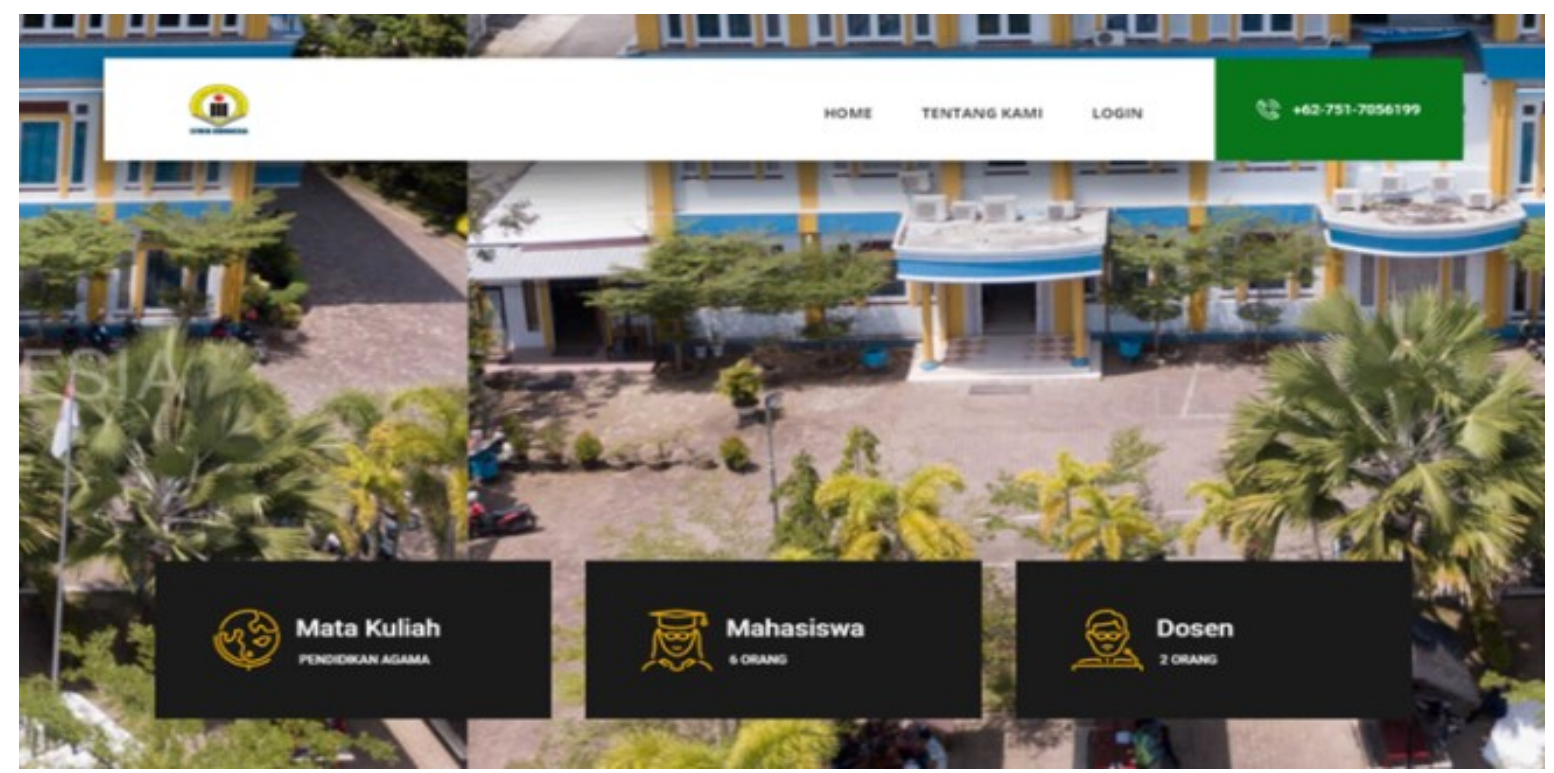

Figure 9: Main page display

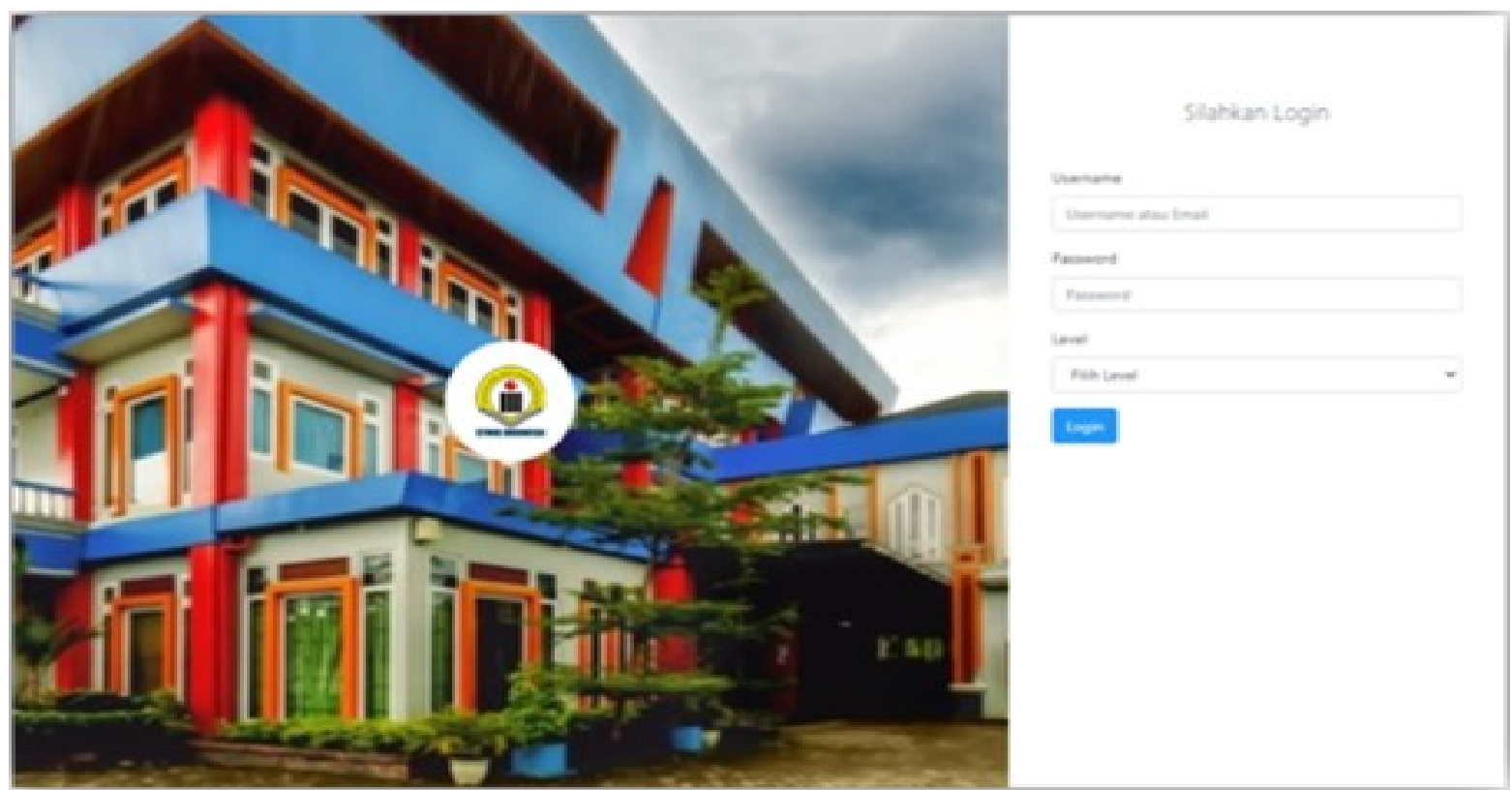

Figure 10: Login page display 


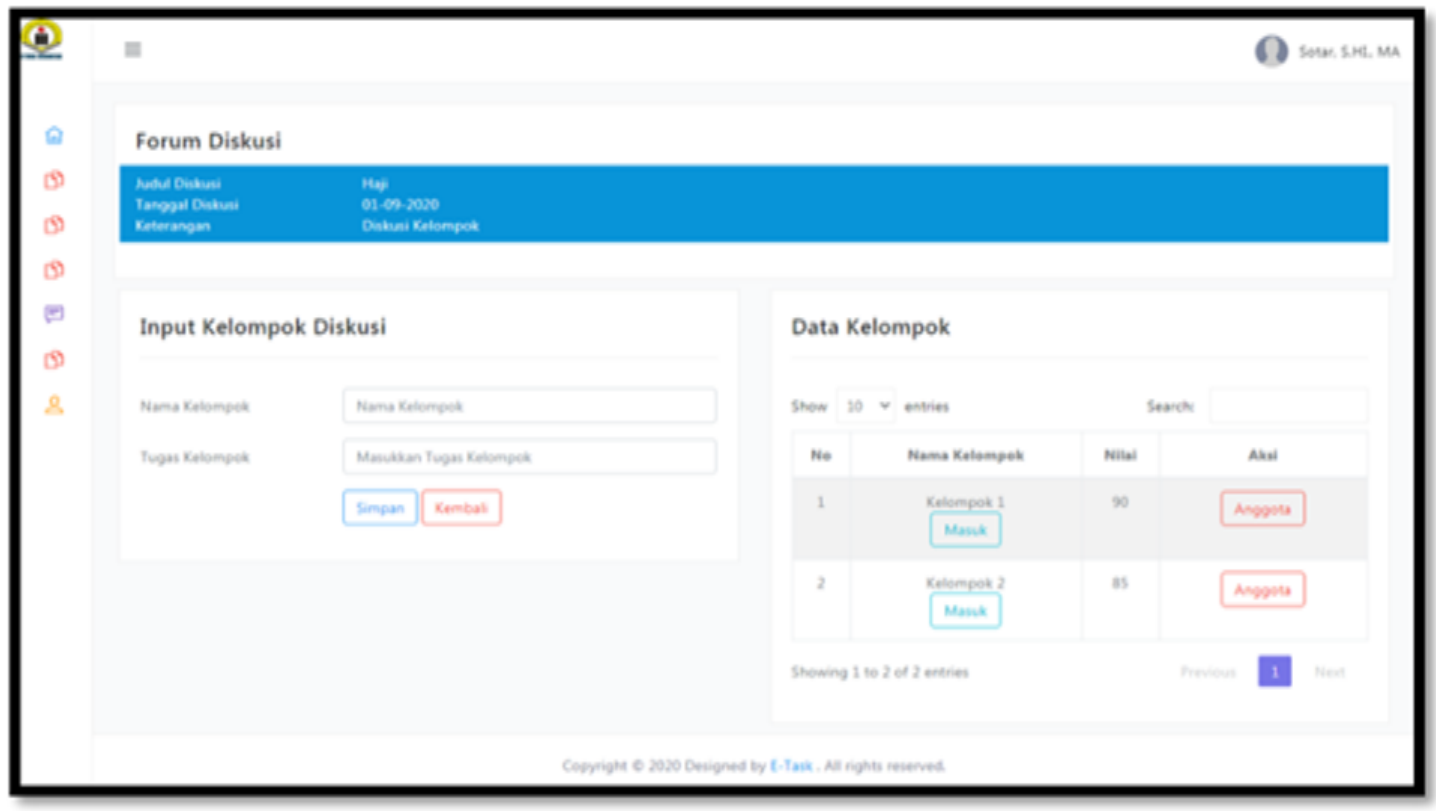

Figure 11: Group data input display

In Figure 11, the group data input is a form used by lecturers to add discussion groups to the forum. It has several attributes such as group names, group assignments, and can see group data inputted, including group names, values and actions of the members' group.

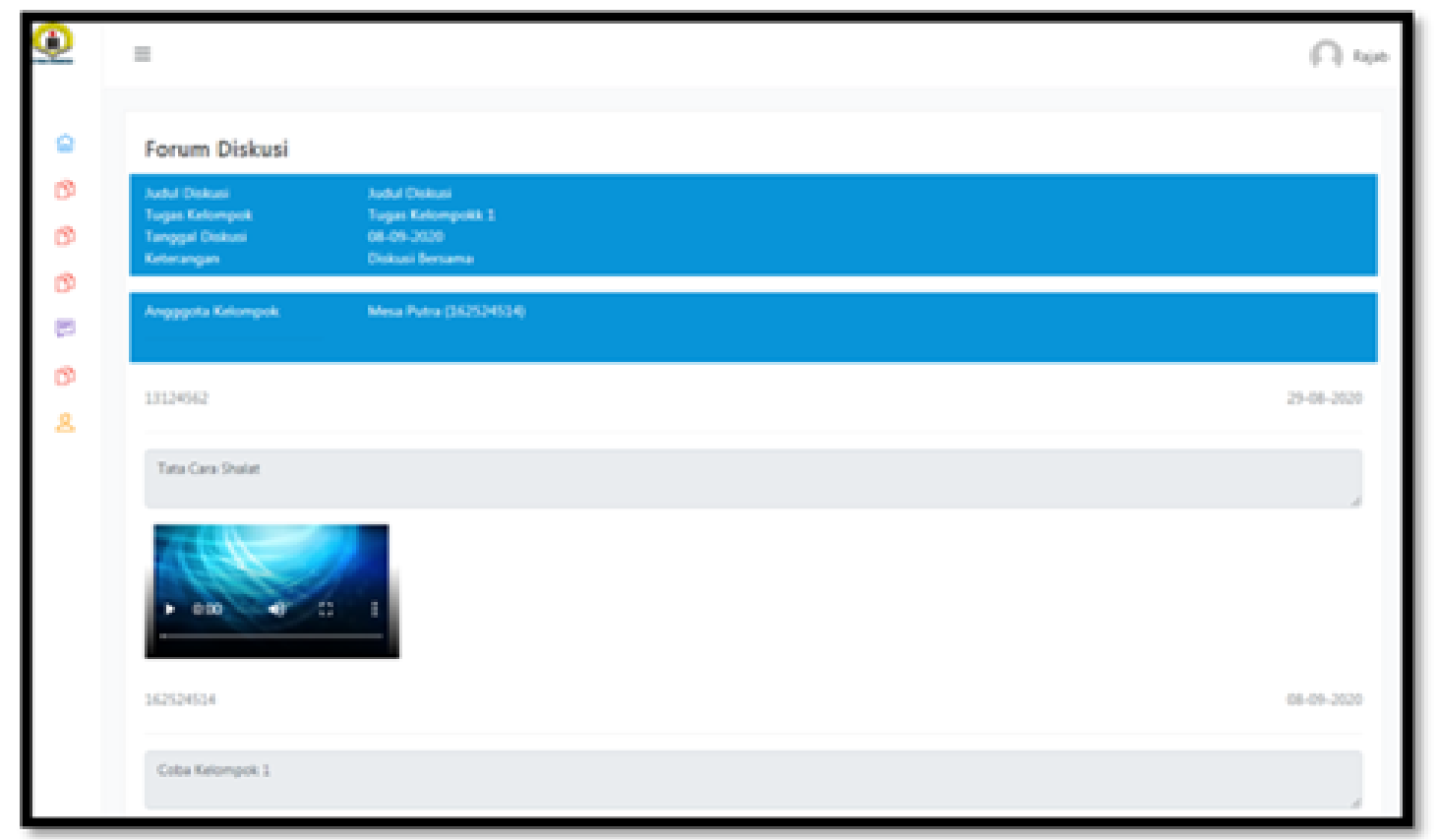

Figure 12: Comment data input display

Figure 12 shows the display of comment data input, which is the form used by lecturers and students to add comments to the discussion forum.

\subsection{Testing Research Results}

The primary test of applying the GIETAL model in universities is carried out using the black box method, emphasizing system functionality. The test's success level is measured from the fulfilment of the requirements specifications and system scenarios. Testing is done by running the system, then observing whether the results are under the requirements specification. Tests performed on system functions are presented in Table 6. 
Table 6: Testing module

\begin{tabular}{|l|l|l|l|}
\hline \multicolumn{2}{|c|}{ System Description System } & Testing ProcedureSystem & Results ofTesting \\
\hline $\begin{array}{l}\text { Before Research } \\
\begin{array}{l}\text { Difficulty in giving } \\
\text { lecturer is unable to attend }\end{array}\end{array}$ & $\begin{array}{l}\text { The entry menu appears. } \\
\text { Enter the username and } \\
\text { password and select the } \\
\text { level }\end{array}$ & & $\begin{array}{l}\text { Successfully login, and the } \\
\text { dashboard page appears. }\end{array}$ \\
\hline $\begin{array}{l}\text { The learning process is still } \\
\text { manual, so it takes time in } \\
\text { the task collection process. }\end{array}$ & $\begin{array}{l}\text { Applying the Group } \\
\text { Investigation E-Task in } \\
\text { Activities Learning (GIETAL) } \\
\text { learning model in } \\
\text { universities can simplify } \\
\text { collecting tasks and } \\
\text { processing data more } \\
\text { quickly and effectively. }\end{array}$ & $\begin{array}{l}\text { Click, and the task } \\
\text { collection menu will } \\
\text { appear }\end{array}$ & $\begin{array}{l}\text { Students can collect } \\
\text { assignments given by the } \\
\text { lecturer, and the lecturer } \\
\text { provides an assessment } \\
\text { based on the works } \\
\text { collected by students. }\end{array}$ \\
\hline
\end{tabular}

\subsection{Analysis Of The Results Of The Implementation Of The Research}

1. Validity Test Data

The data of the validity test obtained are shown in Table 7.

Table 7: Obtaining validity tests from experts

\begin{tabular}{cccc}
\hline Aspect Validation & Total Score & Validity Value (\%) & Criteria for \\
\hline E-Learning Content & 47 & 85.45 & Valid \\
E-Learning Design & 52 & 86.67 & Valid \\
\hline Total Score/Validity Value/category & 110 & 86.06 & Valid \\
\hline
\end{tabular}

Based on Table 7, the GIETAL model validity test results for the Database Design course for the content aspect were valid (85.45\%). In comparison, the GIETAL model validation for the design aspect got a valid score (86.67\%). The average GIETAL model validation results for both aspects get a valid value (86.06\%). It can be stated that online learning using the GIETAL model for the Database Design course is declared valid as a learning medium during the covid-19 pandemics. Staff

2. Practicality Test Data

1. Data from Teaching Test

Data obtained from lecturers are presented in Table 8 as follows:

Table 8: Obtaining test the practicalities of lecturers

\begin{tabular}{lcccc}
\hline \multirow{2}{*}{ Section Measurement } & \multicolumn{4}{c}{ Summation } \\
\cline { 2 - 4 } & $\mathbf{R 1}$ & $\mathbf{R 2}$ & Mean & \multirow{2}{*}{ Qriteria } \\
\hline Ease of Use & 45 & 90 & 67.5 & Quite Practical \\
Effectiveness of time & 45 & 70 & 57.5 & Less Practical \\
Interpretation of the media & 90 & 95 & 92.5 & Very Practical \\
Equivalence & 40 & 90 & 65 & Pretty Practical \\
\hline Mean & $\mathbf{5 5}$ & $\mathbf{8 6 . 2 5}$ & $\mathbf{7 0 . 6 2}$ & Pretty Practical \\
\hline
\end{tabular}

R1 = Lecturer1 R2 =Teaching2

Based on Table 8, the data from the practicality test of online learning using the GIETAL model for the Database Design course, for ease of use of the GIETAL model, is quite practical $(67.50 \%)$. The practicality of online learning using the GIETAL model for the effectiveness of the teaching staff's time got a less practical score (57.50\%). The practicality of online learning using the GIETAL model for the interpretation aspect of the GIETAL model gets a very practical score (92.50\%). The practicality of online learning using the GIETAL model for the equivalence aspect gets a fairly practical score (65\%). Overall, all the results of online learning validation using the GIETAL model for the four aspects got quite practical scores (70.62\%). So it can be said that online learning using the GIETAL model for the Database Design course is quite practical as a learning medium based on the assessment of the teaching staff during the covid 19 pandemic. 
2. Practicality Test Data Based on Student Responses

Data on the acquisition of practicality tests from students are presented in Table 9.

Table 9: Summary of achievements test the practicalities of learners

\begin{tabular}{ccc}
\hline Section Measurement & Summation & Criteria \\
\hline The simplicity of use models GIETAL & 78.14 & Pretty Practical \\
Effectiveness of time usage models metal & 71.85 & Pretty Practical \\
The appeal of the use of models GIETAL & 79.75 & Pretty Practical \\
\hline Average & $\mathbf{7 6 . 5 8}$ & Pretty Practical \\
\hline
\end{tabular}

Based on Table 9, the test result data shows the practicality of online learning using the GIETAL model for the Database Design course. In terms of the simplicity of using the GIETAL model, the score is quite practical (78.14\%). Furthermore, practicality for time effectiveness using the GIETAL model gets a fairly practical score (71.85\%). Finally, practicality for the attractiveness aspect of using the GIETAL Model gets a fairly practical score $(79.75 \%)$. On average, all three aspects of online learning validation results using the GIETAL model got quite practical scores (76.58\%).

\section{Effectiveness}

The results of the effectiveness test for students' learning outcomes are presented in Table 10.

Table 10: Effectiveness

\begin{tabular}{|ll|}
\hline Number of Students $\mathbf{=} \mathbf{5 4}$ Students \\
\hline Students passed & Students did not pass \\
\hline 51 students $(94.44 \%)$ & 3 students (5.56\%) \\
\hline
\end{tabular}

Based on Table 10, the data on the online learning effectiveness test results using the GIETAL model based on student learning outcomes. Fifty-one students who passed were categorized as very effective (94.44\%). Meanwhile, the number of students who did not pass online learning using the GIETAL Model was three students (5.56\%). So it can be said that online learning using the GIETAL model for the Database Design course was very effective as a learning medium during the covid 19 pandemics.

\section{Conclusion}

This study resulted in a learning model in developing student group assignments, with the model name Group Investigation E-Task in Activities Learning (GIETAL) implemented in Higher Education. This model has been implemented in the Database Design course for the Information Systems Study Program at STMIK Indonesia Padang. Based on the results of the discussion on validity, it can be concluded that the validity of the GIETAL model of learning media applied for online learning during the Covid 19 pandemic, overall from the two aspects that have been tested, has a valid value (86.06\%). It means that the GIETAL Model learning media is valid to be used as an online learning medium during covid 19 in terms of content and design.

Based on the results of the practicality discussion, it can be concluded that overall, from the two aspects tested, the score is valid (83.33). It means that the GIETAL Model learning media is practical for use as an online learning medium during covid 19 , based on the responses from the teaching staff and students. Based on the discussion results for effectiveness, it can be concluded that the GIETAL Model learning media which was applied for online learning during the covid 19 pandemic based on student learning outcomes, was very effective. The GIETAL model improves student learning outcomes, as evidenced by 51 students (94.44\%) who passed and passed the minimum criteria set in the semester learning plan.

\section{Acknowledgement}

On this occasion, we would like to thank the Amal Bakti Muslimin Foundation, STMIK Indonesia Padang, which has provided financial support in writing this journal to completion according to contract number 009/KA/LPPM/STMIK-I/2020. The author would also like to thank the Chairperson of STMIK Indonesia Padang and the Chairperson of LPPM. They have encouraged and motivated their lecturers to continue producing high-quality research. 


\section{References}

Alsobhi, A., Y., Alyoubi. K., H., 2020. Learning styles and dyslexia types understanding their relationship and its benefits in adaptive e-learning systems. International Journal of Interactive Mobile Technologies, 14(15), pp. 25-43. https://doi.org/10.3991/ijim.v14i15.16129

Aparicio, M., Bacao, F., and Oliveira, T., 2016. An e-learning theoretical framework. Educational Technology and Society, 19(1), pp. 292-307. https://www.jstor.org/stable/jeductechsoci.19.1.292.

Arinda, Yhona, Wilujeng, I., and Kuswanto, H., 2019. The application Group Investigation ( GI ) learning model assisted phet to facilitate student scientific work skills. International Journal of Educational Research Review, 4(2), pp. 254-261. http://dx.doi.org/10.24331/ijere.518069.

Chen, X., 2018. Design and implementation of university art education management system based on java technology. International Journal of Emerging Technologies in Learning,13(10), pp. 83-94. https://doi.org/10.3991/ijet.v13i10.9452.

Chootongchai, S., and Songkram, N., 2018. Design and development of SECl and Moodle online learning systems to enhance thinking and innovation skills for higher education learners. International Journal of Emerging Technologies in Learning, 13(3), pp. 154-172. https://doi.org/10.3991/ijet.v13i03.7991

Fachrizal, M., R., and Ramadhan, F., 2018. Design of web-based e-learning application. IOP Conference Series: Materials Science and Engineering. International Conference on Informatics, Engineering, Science and Technology (INCITEST), 9 May 2018, Bandung, Indonesia, 407, 012138. https://doi:10.1088/1757-899X/407/1/012138

Harsono, 2008. Student-centered learning in college. Indonesian Journal of Medical Education and Health Profession, 3(1), pp. 4-8.

Hursen, C., Bas, C., 2019. Use of gamification applications in science education. International Journal of Emerging Technologies in Learning, 14(1), pp. 4-23.

Liu, Y., and Zhao, X., 2017. Design flow of english learning system based on item response theory. International Journal of Emerging Technologies in Learning,12(12), pp. 91-102.

Liu, Z., Y., Lomovtseva, N., and Korobeynikovand, E., 2020. Online learning platforms: reconstructing modern higher education. International Journal of Emerging Technologies in Learning, 15(13), pp. 4-21. https://doi.org/10.3991/ijim.v14i15.16129

Maulana, I.,T., Hary, R.,D., Purwasih, R., and Firdian, F., 2019. Project-based learning model practicality on local network devices installation subject. International Journal of Emerging Technologies in Learning, 14(15), pp. 94-106. https://doi.org/10.3991/ijet.v14i15.10305

Mystakidis, Stylianos, Berki, E., and Valtanen, J., 2019. The patras blended strategy model for deep and meaningful learning in quality life-long distance education. Electronic Journal of e-Learning, 17(2), pp. 66-78. https://doi.org/10.34190/JEL.17.2.01

Ningsih, S.,R., Effendi, Z.,M., and Syah, N., 2019. Implementation of cooperative learning model on e-assignment responsiveness at higher education. International Journal of Emerging Technologies in Learning, 14(18), pp.209-219. https://doi.org/10.3991/ijet.v14i18.10752

Ningsih, S.,R., Suryani, A.,I., Aulia, P., 2019. Student center learning-based e-task application in information systems project management courses. Journal of Information Technology, 8(1),pp. 37-49.

Nortvig, Mette, A., Petersen, A., K., and Balle, S., H., 2018. A literature review of the factors influencing e-learning and blended learning in relation to learning outcome, student satisfaction and engagement. Electronic Journal of eLearning, 16(1), pp. 46-55. https://files.eric.ed.gov/fulltext/EJ1175336

Pratami, A., Z., Suhartono, and Salimi, M., 2019. Application of the investigation learning model to improve social science learning outcomes. Social Harmony, Social Sciences Education Journal, 6(2), pp. 164-74.

Sangadji, S., 2016. Implementation of cooperative learning with group investigation model to improve learning achievement of vocational school students in Indonesia. International Journal of Learning \& Development, 6(1), pp. 91-103. http://dx.doi.org/10.5296/ijld.v5i3.9128

Santyasa, I., W., Kanca, I., N., Warpala, I., W., and Sudarma, I., K., 2019. Group investigation and explicit learning models in learning physics at senior high schools. Journal of Research and Development of Physical Education, 5(2), pp.203-216. https://doi.org/10.21009/1.05216

Tawafak, R., M., Alfarsi, G., Jabbar. J., Malik. S., I., Mathew. R., Alsidiri. A., Shakir, M., and Romli. A., 2021. Impact of technologies during covid-19 pandemic for improving behavior intention to use e-learning." International Journal of Interactive Mobile Technologies, 15(01), pp. 184-198.

Wang, Jian, 2019. Application of blending learning based on network learning space in teaching design of digital art state of the art. International Journal of Emerging Technologies in Learning, 14(3), pp.17789.https://doi.org/10.3991/ijet.v14i03.10107

Zidoun, Y., Dehbi, R., Talea. M., and Arroum, F., Z., 2019. Designing a theoretical integration framework for mobile learning. International Journal of Interactive Mobile Technologies,13(12), pp.152-170.

https://doi.org/10.3991/ijim.v13i12.10841 